\title{
Smart tourism destinations: ecosystems for tourism destination competitiveness
}

Article

Accepted Version

Boes, K., Buhalis, D. and Inversini, A. (2016) Smart tourism destinations: ecosystems for tourism destination competitiveness. International Journal of Tourism Cities, 2 (2). pp. 108-124. ISSN 2056-5607 doi:

https://doi.org/10.1108/IJTC-12-2015-0032 Available at https://centaur.reading.ac.uk/75357/

It is advisable to refer to the publisher's version if you intend to cite from the work. See Guidance on citing.

Published version at: https://doi.org/10.1108/IJTC-12-2015-0032

To link to this article DOI: http://dx.doi.org/10.1108/IJTC-12-2015-0032

Publisher: Emerald

All outputs in CentAUR are protected by Intellectual Property Rights law, including copyright law. Copyright and IPR is retained by the creators or other copyright holders. Terms and conditions for use of this material are defined in the End User Agreement.

\section{www.reading.ac.uk/centaur}

\section{CentAUR}

Central Archive at the University of Reading 
Reading's research outputs online 


\title{
From Smart Cities to Smart Tourism Destinations: Ecosystems for tourism destination competitiveness
}

\begin{abstract}
The concepts of smart cities and smart tourism destinations have gained momentum in recent years. They aim of both is to enhance the competitiveness of a places and improve the quality of life for both residents and tourists. To date the concept of smartness, which characterises everything that is embedded or enhanced by Information and Communication Technologies (ICT), mainly emphasises how interoperable systems can integrate functions that have the ability to manage big data and generate value for all stakeholders. Grounded in Service-Dominant logic, this paper explores the core components of smartness in the context of smart cities and smart tourism destinations. The research conceptualises smartness and argues that ICT, leadership, innovation, and social capital supported by human capital are core components of smartness. In fact, although ICT is a critical enabler for smart cities and smart tourism destinations, it is insufficient on its own to introduce smartness. A comprehensive framework is offered to demonstrate how smartness can support tourism destination competitiveness.
\end{abstract}

Keywords: Smart City, ICT, Smart Tourism Destinations, Tourism, Competitiveness

\section{Introduction}

Economies and societies have always been subject to change. Yet change has never been so intense and come at such a high speed as in recent years (Porter \& Heppelmann, 2014). Current global forces influencing the world have never been more complex and challenging and are causing disruptive changes in all aspects of society (Dedehayir, Ortt, \& Seppanen, 2014). In order to be prosperous as an organization in this changing society, it is critical to understand how to adapt to these global forces and how to use them as an advantage. Technological changes have always been essential to tourism (Hjalager, 2010) and recent developments initiating the smartness concept have been recognised to cause a paradigm shift within the tourism industry (Buhalis, 2015).

The smartness concept originated as a complex technological infrastructure embedded within urban areas to foster economic, social and above all environmental prosperity (IBM, 2014). It relates to the implementation of ICT to improve processes (Buhalis, 2015) while simultaneously focusing on the social challenges imposed by urbanism (Caragliu, Del Bo, \& Nijkamp, 2011). This implication of cutting-edge technology for the enhancement of current global societal challenges triggered concepts such as the 'Smart Planet' (IBM, 2014), 'Smart City' (Hollands, 2008) and more recently, the 'Smart Tourism Destination' (Buhalis \& Amaranggana, 2014). Within all these 'smart concepts', the connection between society and technology reintroduced the socio-technical paradigm (Orlikowski, 1992), in which people and technology are connected and perceived as equal actors (Latour, 2005; Meijer \& Bolívar, 2015) that collaboratively create economic, social and environmental prosperity for all actors involved. 
Cities and tourism destination, as contexts for the smartness concept, have been perceived as complex ecosystems with a vast range of stakeholders that ultimately collaborate to create value for themselves and others (Gretzel, Werthner, Koo, \& Lamsfus, 2015; McKercher, 1999; Scott, Baggio, \& Cooper, 2008). The public sector started to recognize the potential of smartness and understanding the need to adapt to this rapid change in technology: governments as well as public and private agencies in cities and tourism destinations started to incorporate smartness in new policies and strategies to enhance sustainable development and economic growth (Cocchia, 2014; Meijer \& Bolívar, 2015; Nam \& Pardo, 2011) for all stakeholders in the tourism ecosystem.

A theoretical lens, which could meaningfully address the co-creation of value for all stakeholders in the smart tourism destination, is the recently developed Service-Dominant logic (S-D logic) "world view" (Maglio \& Spohrer, 2012, p.666). S-D logic argues that the collaboration of different actors (i.e. stakeholders) towards value creation (Vargo \& Lusch, 2011a) and postulates their interaction within a dynamic ecosystem (Wieland, Polese, Vargo, \& Lusch, 2012) through the voluntary exchange of operant resources (Vargo \& Lusch, 2011a). Even though S-D logic might lack profoundness to acknowledge the complexity of smart tourism destinations (Wang et al. 2013) and has been criticised for its terminology, the stance towards the meaning of information, or its focus on marketing (Campbell, O'Driscoll, \& Saren, 2012), it has become a recognised approach towards explaining the concept of value co-creation in different disciplines (Cabiddu et al., 2013; Shaw, Bailey, \& Williams, 2011); thus it could provide an understanding of the process towards value co-creation in smart tourism destinations.

Smartness has gained significant attention from tourism practitioners especially in Spain and China (Lopez de Avila, 2015), however, research within this field is still in its early stages and scholars have mainly emphasised the prominent role of technology (Buhalis \& Amaranggana, 2014; Gretzel et al., 2015; Wang, Li, \& Li, 2013). Still, value co-creation in a smart ecosystem moves beyond the exclusivity of technology: even though technology is a critical component and takes on different roles within the value co-creation process (Orlikowski, 1992; Akaka and Vargo, 2014), it is ultimately the connection between human actors, which is essential (Latour, 2005; Akaka and Chandler, 2011) to generate value.

To date, the understanding of the additional components such as human actors and their interaction with technology for the implication of value co-creation and smartness in tourism destinations, is limited (e.g. La Rocca, 2014). Consequently, the aim of this paper is to (i) conceptualise the core components of smartness, (ii) provide an understanding how these core components are connected to co-create value in smart tourism destinations taking on a S-D logic research stance, and (iii) present a framework to visualise the elements of the smart tourism destination. First, this paper assesses the literature on the concept of smart cities and the early discussion on smart tourism destinations. Second, the paper explores the core 
components of smartness through case studies of well-established smart cities. The combination of hard and soft smartness components within a S-D logic ecosystem structure holds the potential for sustained competitive advantage and enhancement of quality of life of both residents and tourists in smart tourism destinations. Additionally, the research extends the application of S-D logic to the context of smart tourism destinations, specifically to examine the smartness concept as a means for competitiveness in tourism destinations.

\section{Smartness and Smart Places}

\subsection{S-D logic ecosystems}

The amalgamated organisation of tourism destinations (Buhalis 2000), where stakeholder coopetition and collaboration creates economic, social and environmental value for all involved (Ritchie \& Crouch, 2003), has often been perceived as a complex ecosystem difficult to manage (Fyall, 2011). From the S-D logic perspective such an ecosystem has been defined as a relatively self-contained, self-adjusting system of resource-integrating actors connected by shared institutional logics and mutual value creation through service exchange (Vargo \& Lusch, 2011b). Through this lens, tourism destination stakeholders are resourceintegrating actors interconnected through the organisational premises of the tourism destination and the mutual and voluntary exchange of knowledge and skills: it is the interaction and interrelation between these different actors that form a specific whole (i.e. the tourism destination) as well as the interrelation of this 'whole' with the environment (von Bertlanffy, 1972) which forms the philosophy of S-D logic. S-D logic philosophy, overall explores the interaction between all ecosystem actors, the social norms present within the ecosystem, and the reintegration of resources for innovation and value co-creation (Akaka \& Vargo, 2014). These foundational premises are central in order to understand the value co-creation and the innovation process within smart cities and smart tourism destination (Cohen, 2014a) .

Still, S-D logic is not exclusive in explaining the theoretical stance of the smartness or the smart tourism destination concepts. For example Actor-Network-Theory (ANT) may support a better understanding of the ecosystem structure of smart tourism destinations (Latour, 2005). Actually, whereas S-D logic only recently initiated the role of technology within the ecosystem (Akaka and Lusch, 2014), ANT has long taken on a socio-technical stance towards ecosystems in which human and technology are equal actors (Latour, 2005). Even though ANT can be seen as a constructivist approach, it has been criticised for this and described as a theory lacking the ability to explain social processes (Whittle \& Spicer, 2008). S-D logic is likewise located within the constructivist epistemology, however situates itself in the less extreme social constructionism and has an increase focus on the artefacts co-created through the social interactions within the ecosystem (Vargo \& Lusch, 2008). Consequently, ANT provides a meaningful theoretical stance towards understanding the unique connection between cuttingedge technology and human actors in smartness (Latour, 2005). However, it is the S-D logic 
perspective and its focus on the interaction between ecosystem actors which supports the possibility of gaining an understanding of the co-creation process and innovations in economic, social and environmental dimensions in the smart tourism destination, perceived as the ultimate goal of smartness.

Value co-creation is essential in smart tourism destinations and S-D logic posits, "value is always co-created and is uniquely and phenomenological determined by the beneficiary" (Vargo \& Lusch, 2008, p.7). In this context, value is always co-created between the value provider and the value beneficiary. Prahalad and Ramaswary (2004) were the first to posit the concept of value co-creation. Their framework provides a straightforward explanation of the process in which value is always collaboratively created between the producer and the consumer. Even though the majority of the scholars implementing S-D logic for the explanation of value co-creation initially also implemented this viewpoint (Cabiddu et al., 2013; Frow 2014), it limits the profoundness of the smart tourism destination where value is always co-created with and for residents, the private sector, public organisations, the government, and tourists (Cohen, 2011). S-D logic postulates, "all social and economic actors are resource integrators" (Vargo \& Lusch, 2008, p.7) and thus posits the inclusion of all actors in the smart tourism destination within the value co-creation process, exceeding the more limited view of Prahalad and Ramaswamy (2004). Another limitation of Prahalad and Ramaswamy's (2004) framework is the centralisation of the customer experience in the value co-creation process. From their perspective the customer experience is the ultimate goal, however in the context of smart tourism destinations, the enhancement of the tourist experience is only one of the desired outcomes since the increase in economic, social and environmental prosperity, which is the ultimate goal of smart city and smart tourism destinations (Caragliu et al., 2011).

Even though S-D logic has only recently been used within the field of strategic management and may not be complete enough to explain value co-creation in an holistic way for explaining the complexity of the smart tourism destination (Wang et al. 2013), it can be perceived as a valuable perspective for exploring value co-creation and innovation in smart tourism destinations.

\subsection{Smart Places}

S-D logic introduces the notion of value co-creation orchestrated through the voluntary exchange of resources between ecosystem actors (Prahalad and Ramaswamy, 2004). At first, smartness mainly related to the implementation of cutting-edge technology within the physical urban environment (Cohen, 2015). However, increasingly academic and industry focused research has induced a more mature perspective of smartness, proliferating the development of a holistic framework for theory in which co-creation has become a common practise (Meijer \& Bolívar, 2015).

One aspect of smartness, which receives mutual agreement is ICT and identified as hard smartness within the context of this paper. Developments in technology have enabled the 
collection, transfer and analysis of datasets larger than ever before, providing real-time insights of digital and physical worlds (De Filippi, 2015). Commonly referred to as 'Big Data' and stored in data warehouses called the 'Cloud', these data streams provide novel and powerful insights about behaviour, business transactions and human impacts, enabling real-time decisionmaking. This increases the efficiency and effectives of processes and thus provides the ability to develop competitive advantage for smart places (Buhalis \& Amaranggana, 2014; Wang et al., 2013). Thus: smartness takes advantage of interconnectivity and interoperability of integrated technologies to reengineer processes and data in order to produce innovative products and procedures (Buhalis, 2015). Even though this perspective emphasises the essence of ICT, smart grid and sensor technologies are components of a smart city strategy, but their use does not mean a city is smart already (Cohen, 2012). Recognising the complexity of smartness and understanding social, economical and environmental transformations in urban structures, fostered and supported by novel technologies initiated a growing focus on the additional components (Albino, Berardi, \& Dangelico, 2015; Meijer \& Bolívar, 2015) of the ecosystem structure of smart places.

However, technology and thus hard smartness "on itself, has no power, does nothing. Only in association with human agency, social structure and organisation does technology fulfil functions" (Geels, 2002, p.1257). Consequently, to enhance competitiveness, soft smartness components, deduced from soft infrastructure (Wakelin, 1992), are essential to give meaning to hard smartness. Components such as the presence of a knowledgeable workforce (Berry \& Glaeser, 2005) which integrates all members of the society (Malek \& Costa, 2015; Porter \& Kramer, 2011; Vargo \& Lusch, 2008) contribute to the success of smartness in smart places. Smart places (being them smart cities or smart tourism destinations) have an inner complexity (Cohen, 2012). While the literature on smartness, smart cities and smart tourism destinations is increasing, the concept remains fragmented (Meijer \& Bolívar, 2015). This is illustrated by the disparity between the formulated definitions on smart cities (Table 1), proposing perspectives ranging from a sole techno-centric and centralised concept (Smart Cities Council, 2015) to a dynamic, open, collaborative and social-centric view (Caragliu et al., 2011; Meijer \& Bolívar, 2015).

Table 1: Definitions Smart Cities 
"A smarter city infuses information into its physical infrastructure to improve conveniences, facilitate mobility, add efficiencies, conserve energy, improve the quality of air and water, identify problems and fix them quickly, recover rapidly from disasters, collect data to make better decisions and deploy resources effectively, and share data to enable collaboration across entities and domains. Its operations are instrumented and guided by performance metrics, with interconnections across sectors and silos."

"A city [is] smart when investments in human and social capital and traditional (transport) and modern (ICT) communication infrastructure fuel sustainable economic growth and a high quality of life, with a wise management of natural resources, through participatory governance."

Moss Kanter and Litow

$(2009$, p.2)

"A smart city is a well defined geographical area, in which high technologies such as ICT, logistic, energy production, and so on, cooperate to create benefits for citizens in terms of well being, inclusion and participation, environmental quality, intelligent development: it is governed by a well defined pool of subjects, able to state the rules and policy for the city government and development."

"A smart city is an urban environment which, supported by pervasive ICT systems, is able to offer advanced and innovative services to citizens in order to improve the overall quality of their life"

"A smart city [is a city] that has digital technology embedded across all city functions."

Caragliu, Del Bo \& Nijkamp (2011, p.70)

"The smartness of a city refers to its ability to attract human capital and to mobilize this human capital in collaborations between the various (organized and individual) actors through the use of information and communication technologies."

Dameri (2013, p.2549)

As it is possible to understand from table 1, the ultimate goal of smart places is to increase competitiveness and enhance quality of life for residents and visitors (Buhalis \& Amaranggana, 2014; Caragliu et al., 2011). A broad range of aspects should be included to reach this outcome. In order to provide smart city initiators and developers with a guideline of standardised aspects to focus on, Cohen (2011) conceptualised the Smart City Wheel which defines six smartness dimensions, including: (1) Smart Governance, (2) Smart Environment, (3) Smart Mobility, (4) Smart Economy, (5) Smart People, and (6) Smart Living. Hence, to develop a smart city and gain a sustained competitive advantage it requires an on going process, which incorporates technology (Hollands, 2008) and recognises the prominence of people (Cohen, 2015; Moss Kanter \& Litow, 2009; Nam \& Pardo, 2011) guided by institutional logics in the form of dynamic leadership (Spencer, Buhalis, \& Moital, 2012; Vargo \& Lusch, 2011a).

Therefore, bearing in mind the relevance of technology in discussing smart cities and smart tourism destinations, the aim of this research is to shade lights on the importance of soft components for smart tourism destinations and to design a comprehensive framework to demonstrate how smartness can support tourism destination competitiveness.

\section{Methodology}

Given the exploratory nature of this paper and the contemporary character of the research topic, a case study approach was adopted (Yin, 2009). This approach has frequently been implemented in tourism (Beeton, 2005) when research is still in its early, formative stage 
(Benbasat, Goldstein, \& Mead, 1987). Smartness has only recently gained momentum in different disciplines and is still rather young (Dameri \& Rosenthal-Sabroux, 2014; Meijer \& Bolívar, 2015). Adopting the case study approach enabled the researchers to gain holistic insights regarding the core components of smartness, through the analysis of reports, studies, news articles and other text sensitive documentation.

\subsection{Case selection}

Smart cities initiated the notion of smart tourism destinations (Buhalis \& Amaranggana, 2014). Hence, they are more mature in implementing smartness and thus provided the context for this research. Currently a variety of smart cities have been developed and to justify the selection of the cases, two international ranking schemes were used. First, the smart city classification by Cohen (2014b) was used to inform case selection since this classification syndicates a variety of global and regional rankings. This selection identified a long list of the top ten smart cities. In order to narrow down these cases, the study on smart cities undertaken by the European Union (2014) was also taken into account. This particular study, "Mapping Smart Cities in the EU", conducted an in-depth analysis of the cities within the EU28 with at least 100,000 residents. A selection of 240 cities was identified as 'smart'. After a quantitative analysis of the characteristics and contributions of these cities, six top performing cities where identified, including: Amsterdam, Barcelona, Copenhagen, Helsinki, Manchester and Vienna. Out of these six, Barcelona, Amsterdam and Helsinki were ranked as the three cities that yielded the most innovative smart solutions in Europe and were selected as cases for this research.

\subsection{Data collection}

To collect information about the selected cases, three main databases/research strategies were used to search for relevant documents (i.e. Google, Google Scholar and EBSCO) following a five steps methodology (Denyer \& Neely, 2004): (1) key phrase identification, (2) document identification, (3) quality assessment, (4) data extraction, and (5) data analysis. Each step is described in more detail in the following sections.

Within the first step of this systematic process key phrases were identified for the document identification carried out in the second step. The key phrases identified were 'Barcelona smart city case study', 'Barcelona smartness concept', 'Barcelona smart city analysis', 'Barcelona smart city strategy', and 'Barcelona smart city initiative' respectively. The same key phrases were utilised for Amsterdam and Helsinki.

In the second step, the described key phrases were used to identify documents on the selected cases Barcelona, Amsterdam and Helsinki. The identification took place over a threeweek period between 24 September and 15 October 2014. Google was used to query the key phrases and the documents presented on the first three result pages were chosen for further selection. Search results from Google, Google Scholar and the EBSCO database were also used to identify further academic sources. The document identification resulted in a wide data collection stemming from existing government reports, academic case studies, online news 
articles, and smart city project descriptions and presentations. Although the analysis of any case study cannot be fully exhaustive, the majority of the in-depth published documents on the cases researched were included in this study.

The third step focused on the quality assessment of the selected documents. Three academic articles were included due to their peer-review assessment. The European Union report, used for the selection of the cases for this research, was the most comprehensive document identified, with an in-depth analysis of Barcelona, Amsterdam and Helsinki. In addition, four smart city projects were included as well as one presentation document, a presentation transcript and one online news article. Commercial documents or reports delivered by technology companies have been excluded to avoid bias. An overview of the various sources used for the empirical research of this study is depicted in Table 2.

Table 2: Resources Case Studies

\begin{tabular}{|c|c|c|c|}
\hline Smart City & Author(s) & Method & Smart City Components \\
\hline \multirow{2}{*}{ Barcelona } & $\begin{array}{l}\text { Bakici, Almirall \& } \\
\text { Warefam (2013) }\end{array}$ & $\begin{array}{l}\text { Case study analysis: } \\
\text { interviews, observation, } \\
\text { secondary data analysis }\end{array}$ & $\begin{array}{l}\text { Smart districts, Living Labs, Infrastructures } \\
\text { (physical \& technological), new services for } \\
\text { citizens, Open Data, Management of Smart } \\
\text { City }\end{array}$ \\
\hline & PWC (2014) & $\begin{array}{l}\text { Desk research: Internal } \\
\text { documents analysis }\end{array}$ & $\begin{array}{l}\text { Vision (IT integration), Collaboration, } \\
\text { Organisation (top-down governance), } \\
\text { Innovation and Citizen participation, Open } \\
\text { Data }\end{array}$ \\
\hline \multirow{4}{*}{ Amsterdam } & Baron (2013) & $\begin{array}{l}\text { Desk research: Internal } \\
\text { documents analysis }\end{array}$ & $\begin{array}{l}\text { Collaboration, Open Data, Citizen } \\
\text { participation, Organic Ecosystem, } \\
\text { Technological infrastructure and } \\
\text { connectivity. }\end{array}$ \\
\hline & Brinkman (2011) & Case study analysis & $\begin{array}{l}\text { Collective effort, Technology push and pull, } \\
\text { Research and knowledge sharing, } \\
\text { Economic viability, Innovations, Cooperation }\end{array}$ \\
\hline & Van Veen (2014) & $\begin{array}{l}\text { Desk research: Internal } \\
\text { documents analysis }\end{array}$ & $\begin{array}{l}\text { Collective approach, Understanding } \\
\text { behaviour, Testing innovations in Living } \\
\text { Labs, Open infrastructures, Open data, } \\
\text { Open innovation, Open knowledge }\end{array}$ \\
\hline & Dameri (2014) & $\begin{array}{l}\text { Case study analysis: } \\
\text { secondary data analysis }\end{array}$ & $\begin{array}{l}\text { Collaboration, Innovation, Virtual community } \\
\text { and involvement of people, Technological } \\
\text { infrastructure, Government }\end{array}$ \\
\hline \multirow{3}{*}{ Helsinki } & $\begin{array}{l}\text { Hielkema \& } \\
\text { Hongisto (2013) }\end{array}$ & $\begin{array}{l}\text { Case study analysis: } \\
\text { interviews and secondary } \\
\text { data analysis }\end{array}$ & $\begin{array}{l}\text { Skilled workforce, Technology, } \\
\text { Collaboration, Innovation, Open data, Living } \\
\text { Labs, Active government }\end{array}$ \\
\hline & GSMA (2012) & $\begin{array}{l}\text { Desk research: Internal } \\
\text { documents analysis }\end{array}$ & $\begin{array}{l}\text { Innovation, Collaboration, Open data, } \\
\text { Competition to drive innovation, Inclusion of } \\
\text { SME's, Mobile Clusters }\end{array}$ \\
\hline & $\begin{array}{l}\text { Forum Virium } \\
\text { Helsinki (2014) }\end{array}$ & $\begin{array}{l}\text { Desk research: Internal } \\
\text { documents analysis }\end{array}$ & $\begin{array}{l}\text { Collaboration and Harmonization; Open and } \\
\text { Transparent Data; (open) Innovation; } \\
\text { Talented People; ICT Infrastructure }\end{array}$ \\
\hline
\end{tabular}




\begin{tabular}{l|l|l|l}
\hline & & & $\begin{array}{l}\text { Vision: Inclusion \& Participation } \\
\text { People: Human Capital - User-centred and } \\
\text { bottom-up; Leadership; Participative } \\
\text { approach - co-creation/collaboration/co- } \\
\text { development }\end{array}$ \\
$\begin{array}{l}\text { Barcelona, } \\
\text { Amsterdam \& }\end{array}$ & $\begin{array}{l}\text { European Union } \\
\text { (2014). }\end{array}$ & $\begin{array}{l}\text { Process: Central office to coordinate cross- } \\
\text { of 468 European "smart } \\
\text { cities" --> In-depth } \\
\text { analysis of 6 top } \\
\text { performing Smart Cities } \\
\text { sectional innovation; Open Data; Close } \\
\text { cooperation with end-user; Sharing } \\
\text { knowledge through Living Labs and } \\
\text { collaboration networks }\end{array}$ \\
\hline
\end{tabular}

The fourth step of the data collection concentrated on the data extraction. An iterative thematic content analysis was carried out in which a bottom-up coding scheme was adopted. The identified codes were deduced from the analysed content (Yin, 2009). A three level coding scheme was used (Bryman \& Bell, 2011) and the three selected cases were separately coded. In the first level, a very basic coding was applied in which paragraphs were analysed for the research. Within this phase content describing, for example, the demographics of the cities was excluded from further analysis. The second level comprised a more in-depth approach in which codes such as 'innovation', 'collaboration', 'work together' and 'human skills' were used to characterise the units of text. After this level 58 codes were deduced from the content on Barcelona, 44 on Amsterdam and 52 on Helsinki.

Data extraction and data analysis were the two intertwined steps within the context of this research. Consequently, the data analysis initiated in the data extraction phase. The third level of coding took a more analytic approach. A cross-case examination (Yin, 2009) of the codes identified in the separate cases on the second level was conducted. Interconnections and differences were identified which provided more compelling and robust outcomes (Gillham, 2000) and consequently 28 codes have been deduced from the analysis. Further engagement with the content and codes identified four main themes, which have been selected as the core components of smartness. The results of this analysis are presented in the following section.

\section{Results}

The results of the case studies demonstrate the presence of an advanced technological info/infrastructure utilised for the management of information and the connection of all social and economic actors within the urban area. Besides the apparent presence of technology or hard smartness, four additional soft smartness components coalesced out of the analysed data sets, (1) innovation, (2) social capital, (3) human capital and (4) leadership. These four components strongly intertwine with hard smartness. Consequently, the role of this info/infrastructure shall be discussed in connection to innovation, social and human capital, and leadership instead of separately. The following sections present the in-depth exploration of the identified components of smartness from the smart city case studies on Barcelona, Amsterdam and Helsinki. 


\subsection{Innovation}

The S-D logic A2A ecosystem provides as more compelling and encompassing perspective to study innovation (Akaka \& Vargo, 2014) by introducing the involvement of all actors within the ecosystem rather than solely focusing on the innovation abilities of private actors. Within this study, innovation has been identified as a core component. However, it can be perceived as an outcome within the S-D logic perspective where it flourishes when all actors collaborate on its development (Vargo, Wieland, \& Akaka, 2015). Innovation has always been significant to competitiveness (Porter, 1998). It is vital for the competitiveness of a smart city (Hielkema \& Hongisto, 2013) as well as the competitiveness of tourism destinations (Pirnar, Bulut, \& Eris, 2012). In the cases of Barcelona, Amsterdam and Helsinki, innovation is the preferred outcome of all practises undertaken and this was highly promoted and strongly influenced by ICT (European Union, 2014). One way of encouraging innovation is through the establishment of Living Labs. Such a "user-centric innovation milieu" is "built on every-day practice and research, with an approach that facilitates user influence in open and distributed innovation processes engaging all relevant partners in real-life contexts, aiming to create sustainable values" (Bergvall-Kåreborn, Ihlström Eriksson, Ståhlbröst, \& Svensson, 2009). Living Labs are critical for innovation practises (Cosgrave, Arbuthnot, \& Tryfonas, 2013) and their implementation in smart cities has been greatly emphasised (Bakici et al., 2013). The results of the current analysis indicate Barcelona, Amsterdam and Helsinki recognise this importance of Living Labs and have implemented this concept within different urban areas. Table 3 depicts examples of innovation projects in Living Labs in the three smart cities.

\begin{tabular}{l|l|l|l}
\hline \multicolumn{1}{c|}{ Smart City } & \multicolumn{1}{|c|}{ Living Lab } & \multicolumn{1}{c}{ Project } & \multicolumn{1}{c}{ Actors } \\
\cline { 2 - 4 } Barcelona & 22@ Barcelona & $\begin{array}{l}\text { 22@CreaTalent - } \\
\text { Development of human } \\
\text { capital }\end{array}$ & $\begin{array}{l}\text { Residents, Media } \\
\text { and Design, ICT, } \\
\text { Energy companies }\end{array}$ \\
\cline { 2 - 5 } & i2CAT & $\begin{array}{l}\text { Sesame to enhance data } \\
\text { transfer through smaller } \\
\text { mobile cells }\end{array}$ & $\begin{array}{l}\text { Telecommunication, } \\
\text { Government, } \\
\text { Sesame business }\end{array}$ \\
\hline \multirow{3}{*}{ Amsterdam } & iBeacon Living Lab & $\begin{array}{l}\text { Tourism routes through } \\
\text { iBeacon integration }\end{array}$ & $\begin{array}{l}\text { Telecommunication, } \\
\text { iBeacon, AMS, } \\
\text { Residents and } \\
\text { Tourists }\end{array}$ \\
\cline { 2 - 5 } & Entire city & Smart Parking & $\begin{array}{l}\text { Local community, } \\
\text { Telecommunication, } \\
\text { Mobypark }\end{array}$ \\
\cline { 2 - 4 } & Kalasatama & Smart urban development & $\begin{array}{l}\text { City, Private } \\
\text { companies and } \\
\text { Residents }\end{array}$ \\
\cline { 2 - 4 } & Entire city & $\begin{array}{l}\text { App contest for tourism } \\
\text { development }\end{array}$ & $\begin{array}{l}\text { Residents, Forum } \\
\text { Virum Helsinki, } \\
\text { Government }\end{array}$ \\
\hline
\end{tabular}

Table 3: Living Lab projects

One prominent example of a Living Lab integrated within the urban space of Barcelona is the 22@ Innovation District. The analysis showed within this geographical area various 
public, private and academic organisations collaborate and cooperate on the development of urban innovations. The area functions under a knowledge-city model (Yigitcanlar, Velibeyoglu, \& Martinez-Fernandez, 2008) and emphasises issues such as economics, mobility, green infrastructures and inclusiveness. The ICT info/infra structure is perceived as the backbone for the development of the innovation within this district (Bakici et al., 2013; PWC, 2014). Other examples of successful Living Labs are the "Nieuw-West" and "IJburg" districts in Amsterdam. Both areas are supported by a substantive technology layer, which is endorsed by the Amsterdam Smart City initiative. Whereas the 22@ Innovation District is primarily based on the collaboration between various organisations, the Living Labs in Amsterdam greatly integrate citizens in the innovation process. Amsterdam's sustainable practises concentrate on projects related to green energy and urban planning. However, new media, co-creative designs and tourism are also topics of interest in these two Living Labs (Dameri, 2014).

In order to drive innovation, technologies such as sensors, smart meters and $\mathrm{Wi}-\mathrm{Fi}$ support the collection of data. This data is made available to all stakeholders in the area enabling the co-creation of innovation and solutions to real-life and local matters. Where Barcelona and Amsterdam are emphasising embedding innovation within the smart city initiatives, Helsinki's smart city concept is part of the Forum Virium Helsinki organisation, which places smartness in the innovation initiative of the city. Helsinki also developed a Living Lab, Arabianranta, where companies, academics, and citizens collaborate in developing innovative solutions. It stimulates innovation in the field of citizen-centric services, by implementing demand and user-driven innovations in which open data is used to address the needs of all stakeholders. Another example of a Living Lab, however not placed in Helsinki but of interest to tourism, is the Lutakko Living Lab. The Lutakko area has around 2000 residents, 4000 students and 200 companies. The focus of this area is on the development of services and experiences, mainly concentrating on tourism. The Living Lab is utilised as a real-life experimental lab in which local businesses and citizens co-create product and service innovations together with the stakeholders of the Living Lab. The University, as an academic institute, plays a prominent role within this process, as local students are integrated in various innovation processes. Both of the Living Labs are owned by the local community and supported by the Forum Virium Helsinki in terms of the development of digital services (Hielkema \& Hongisto, 2013).

Innovation is a critical outcome of the integration of smartness within smart places. Traditionally innovation was a process practised by the few bright, mostly big corporations (Clarysse, Wright, Bruneel, \& Mahajan, 2014). However, the case studies indicated communities typically develop smartness innovations collaboratively. Therefore, Living Labs function as real-life experimental and creative spaces. Developing Living Labs also encourages the innovation process to take place amongst all levels of the community since ICT has been perceived as the backbone of innovation. The efficient and effective dissemination of data in Living Labs, supported by ICT, exhilarates the innovation process (Cosgrave et al., 2013). Within the analysed smart cities, technologies such as sensors, mobile applications and 
information systems are implemented for collecting, processing, and transferring large amounts of data. This data is made accessible to all stakeholders and provides analytics to entrepreneurs, creative communities and research institutions in order to encourage innovation and contribute to the success of a smart city.

\subsection{Human Capital}

S-D logic places knowledge and skill are the core of competitiveness (Vargo \& Lusch, 2008). Human capital has been defined as "the knowledge, skills, competencies and attributes embodied in individuals that facilitate the creation of personal, social and economic well-being" (Keeley, 2007, p.29) and consequently an essential operant resource in the A2A ecosystem. It is closely related to social capital and the two are often referred to as intertwined concepts (Keeley, 2007). The connection between human and social capital could also be indicated in the cases of Barcelona, Amsterdam and Helsinki. The data showed innovative developments, crucial for the success of smart cities (Hielkema \& Hongisto, 2013), are underpinned by welldeveloped human capital (European Union, 2014). In order to support the development of human capital the analysed cases support and enable different educational systems. Barcelona executed this aim through the integrations of the Smart City Campus within the 22@ Innovation District. This campus promotes cooperation and synergies between local, national and international companies, universities, research centres, SMEs and local entrepreneurs. Located within the 22@ area it is supported by an ICT info/infrastructure as well as a network of different companies that utilise their collective knowledge and generate new business opportunities (Bakici et al., 2013). This example showed the development of human capital is supported via the presence of social capital and vice versa.

Where Barcelona developed a Smart City Campus within a Living Lab district, Amsterdam set up the Amsterdam Institute for Advanced Metropolitan Solutions. This provides different learning programs, such as a Master degree, to encourage the education of residents on smart solutions for metropolitan areas. The institute conforms to smartness by empowering the collaboration of different public, private and academic partners (Cohen, 2014a). The academic partners consist of the TU Delft, Wageningen UR (two Dutch universities), the Massachusetts Institute of Technology (MIT) and the independent research group TNO. Different public partners such as Amsterdam Smart City, the City of Boston and Waag Society, and industry partners like KPN, IBM, CISCO and Shell have supported the educational programs (van Veen, 2014). Interlinking collaboration and cooperation practises, this educational institution is built upon these premises, which have been identified as the core components of smartness. The city of Helsinki is also using a similar approach to the development of collective knowledge. It recognises the success of innovative developments are reinforced by the city's human capital (Hielkema \& Hongisto, 2013). Helsinki established a knowledge hub called the Arabianranta Living Lab, which has also aimed at attracting knowledgeable and creative (Forum Virium Helsinki, 2014).

These case studies show enhancing human capital through educating and attracting creative and knowledgeable people is at the core of their success. Smart cities shall be 
perceived as hubs where human capital is developed in a virtuous circle. Networks of connected people collaborate, cooperate and co-create to become smarter and smarter (Albino et al., 2015). Berry and Glaeser (2005) indicated areas with an educated work force and a large number of entrepreneurs constantly driving innovation show a higher economic growth rate. Hence, enhancing human capital propels collective intelligence of people and the cross-linking of knowledge ultimately creating a smart (in the sense of intelligent) city or tourism destination (Albino et al., 2015; Berry \& Glaeser, 2005; European Union, 2014).

\subsection{Social Capital}

Social capital has been defined as "networks together with shared norms, values and understandings that facilitate co-operation within or among groups" (Keeley, 2007, p.103). Rich social capital in geographical areas includes the presence of different networks between people, organisations and communities (Lin, 2001) and collaboration and cooperation between such networks supports collective knowledge and competitiveness (Michaelides, Morton, Michaelides, Lyons, \& Liu, 2013). To enhance the connection between various public, private and academic organisations, Barcelona, Amsterdam and Helsinki have presented themselves as cities implementing a "triple helix" model, a "quadruple helix" model and an "ecosystem" structure respectively (Bakici et al., 2013; Baron, 2013; Forum Virium Helsinki, 2014). This means the encouragement of creating collaboration between what Boyd Cohen (2014a) recognised as a "public-private-professor-people" (5P) partnership. The analysis of the cases show collaboration and cooperation are at the forefront, especially within the Living Lab areas (Bakici et al., 2013; Dameri, 2014; European Union, 2014). Particularly the case of Helsinki indicated a prime example of a rich social capital structure, where the Forum Virium Helsinki places social capital and innovation at the core of smartness and has perceived them as two intertwined concepts (Forum Virium Helsinki, 2014). This component is also emphasised in the smart city study of the European Union. The success of the Amsterdam Smart City platform initiated from its participative approach in which collaboration, co-creation and co-development drive value creation for all stakeholders (European Union, 2014).

The data showed these three smart cities put great emphasis on the establishment of social capital and on the enhancement of collaboration between the various smart city stakeholders. It is recognised short-term benefits of individual competition will have a severe negative effect on the long-term development of the city (Fyall, 2011; Jamal \& Jamrozy, 2006). Smart cities understand competition between stakeholders with the same vision should be eliminated (Fyall, 2011). Instead there should be co-opetition, where there is a combination of collaboration and competition offering greater opportunities (Ritchie \& Crouch, 2003; Tuohino \& Konu, 2014). Barcelona, Amsterdam and Helsinki recognise how capital can connect collective intelligence and co-creation enhance co-opetion through the development of collaborative spaces, such as Living Labs, and by sharing open data. 


\subsection{Leadership}

Leadership corroborated with the presence of institutional logics in S-D logic and is perceived as the shaper of value co-creation (Wieland et al., 2012). Spencer et al. (2012) argue the adoption of technology, the backbone of smartness, depends on the leadership approach. With regard to leadership, different styles are implemented within the three cases. The analysis demonstrates Barcelona is taking a top-down management approach, while Amsterdam and Helsinki are implementing a bottom-up approach. Barcelona initiated the Urban Habitats group, situated under the third deputy major, which has an umbrella function incorporating departments that were previously independent (e.g. environment, human services, energy, water). In line with the Urban Habitats, the city also created a Smart City Personal Management Office (SmartCityPMO), which is coordinating all the projects related to the smart city. Even though Barcelona emphasises the collaboration between public, private, academic organisation and citizens, especially in the 22@ Innovation District, the management and initiatives are often introduced by top-management. On the contrary, Amsterdam and Helsinki have both created platforms based on partnerships between public, private, academic and citizen communities where people living and working in the area commence a variety of smart city activities. Even though a common leadership style responsible for the success of smart cities cannot be identified, strong leadership and determination of authorities are critical to implement smartness (Dameri, 2014).

The bottom-up approach is often argued as typical for smart cities (Baron, 2013). However, this is questionable since the smart city initiatives of Amsterdam and Helsinki, promoted as bottom-up approaches, include a variety of top management and community based organisations. For example, different stakeholders initiated the Amsterdam Smart City innovation platform, including the telecommunications provider KPN, grid manager Liander, the Amsterdam Economic Board collaboration between governmental agencies, research institutes, and businesses, the higher educational institution of Amsterdam and the Council of Amsterdam. The integration of citizens, and in particular the residents of Living Labs, effectively develops the smart city. Apart from smartness not being a pure bottom-up initiative, Dameri (2013) argues that the bottom-up approach often forgets about the importance of governmental bodies. Governments play a crucial role in developing the vision and objectives and managing and providing a quality ICT infrastructure. These are an absolute necessity for successful smartness (Nam \& Pardo, 2011), which would not be feasible without the financial support of city administrations (Dameri \& Rosenthal-Sabroux, 2014). A combination of top-down and bottom-up and participatory governance is more suitable within the smartness notion (Baron, 2013; Caragliu et al., 2011). The development of central offices, such as the Smart City PMO in Barcelona, the Amsterdam Smart City and the Forum Virium Helsinki act as a go-between for ideas and initiatives (European Union, 2014). They are a combination of bottom-up and topdown leadership facilitating participatory governance in the smartness notion.

The data indicates that Barcelona, Amsterdam and Helsinki implement a combination of top-down and bottom-up leadership in which participatory governance is promoted. The central 
smart city offices guide and monitor smart city projects in order to empower the community to co-create and co-develop innovations to real-life problems and issues. They provide a supporting role and enable the usage of open data and ICT infrastructures to ensure the collaboration between various smart city stakeholders and the creation of value for all involved.

\section{The Smart Ecosystem}

S-D logic emphasises "all social and economic actors are resource integrators" and "operant resources are the fundamental source of competitive advantage" (Vargo \& Lusch, 2008, p.7). The findings of this research indicates smart places take on the S-D logic A2A ecosystem structure in which the involvement of all people exchanging knowledge and skills is essential to value co-creation and the success of the smart tourism destination (Vargo \& Lusch, 2008). It underpinned the presence of hard smartness in smart places and identified four soft smartness components critical for adding meaning to hard smartness in ecosystems (Geels, 2002). Still, these core components take on different hierarchal roles within the S-D logic A2A ecosystem. Human capital and people are identified as operant resources (Shaw et al., 2011) and thus as integrators of knowledge and skills within the ecosystem (Vargo \& Lusch, 2008). The dual role of ICT is more complex and has been identified as an operand resource and as an operant resource (Akaka \& Vargo, 2014). In its former role, ICT plays an artefact for the input and output of collecting, analysing and storing data. However, in the latter role ICT is an active and dynamic actor triggering innovation via agile mediation through the capability of integrated, interoperable and interconnected systems (Akaka \& Vargo, 2014). It supports improvements of efficiency and effectiveness of processes response time between all actors involved (Lusch \& Nambisan, 2015) and facilitates human interaction and sharpens the focus on collaboration within the ecosystem. This paper corroborates with the suggestion of Akaka and Vargo (2014) who argued the role of ICT as an operant resource in service ecosystems and thus underpin the assumption that cutting-edge technology within the smartness concept is an active and dynamic resource enabling and triggering competitiveness enhancement.

A unique combination of people and technology resources is postulated, in which ICT has become an equal actor within the S-D logic ecosystem next to the social and economic actors (Vargo \& Lusch, 2008). This socio-technical structure facilitates collectivism (Orlikowski, 1992), in which social capital plays the facilitation role. Within smart places the inclusion of all actors has been emphasised and perceived as essential to simultaneously increase competitiveness and enhance quality of life. Within this process, social capital and human capital are two intertwined components of the smartness concept. Human capital can be perceived as an operant resource (Shaw et al., 2011) whereas social capital takes on the role of a facilitator of collaboration supported by ICT as an operant resource (Lusch \& Nambisan, 2015). Since the co-creation of value is at the core of the smart concept, human capital, ICT and social capital are intermingled components, identified as resources and facilitator, and in this paper defined as contributors to the smartness concept. 
To enhance the development of collective intelligence through the integration of operant resources in the ecosystem, institutional logics (Vargo \& Lusch, 2011a) or leadership is required. Within the context of smart places, leadership should ensure the development of an innovation-fostering environment. For example through the development of Living Labs, people are empowered by a bottom-up management approach to initiate smart ideas and co-create value (Baron, 2013). At the same time, the top-down approach ensures the development of an environment in which innovation is fostered and new ideas can be taken forward (Dameri, 2013). In succinct, human capital and ICT, as core components of the smartness concept, take on the role of resources within smart place ecosystems and are critical to value co-creation and competitiveness (Vargo \& Lusch, 2008). The unique interaction between the two components enhances collaboration facilitated by social capital. The connection of the different components is enhanced through shared institutional logics (Vargo \& Lusch, 2011a) and leadership (Spencer et al., 2012). This enables the co-creation of the innovation component of smartness, identified as the outcome of service exchange between ecosystem actors (Akaka \& Vargo, 2014; Vargo et al., 2015).

After conceptualising the core components of the smartness concept, Figure 1 depicts the conceptual framework for the development of a smart tourism destination. Tourism destination managers should perceive the smart tourism destination as S-D logic A2A ecosystem. This indicates ICT, people and leadership (illustrated in the funnel) are contributors to the smartness concept and should therefore be enhanced and developed. However, separately they are solely individual concepts and only intertwined and interconnected within the smart ecosystem process will they become meaningful contributors for smart tourism destinations. Within the smart process, illustrated at the centre of the framework, the core components identified as the contributors of smartness become intermingled to co-create innovations. ICT, as an operant and operand resource interacting with and supportive to people, is represented by for example sensor and ambient technology, the Internet of Things, edge and cloud computing, and big/open data interoperability. However, insights and agile processes are solely a valuable resource for innovation when brought into contact with human interaction (Geels, 2002). Therefore, smart tourism destinations should focus on attracting knowledgeable people and educate employees, through for example MOOCs (Murphy et al., 2014), peer-education and university programs (AMS, 2014), in different disciplines to enhance the intelligence of the destination (Scott et al., 2008).

Enhancing collective intelligence is essential in smart tourism destinations and can be fostered through the development of Living Labs and creative hubs where people from different disciplines can come together to co-create innovation and value (Cosgrave et al., 2013). In line with the S-D logic A2A ecosystem, knowledge and skills are at the base of all exchange (Vargo \& Lusch, 2004). Therefore, knowledge management is an important discipline (Yigitcanlar et al., 2008) within smartness. Transfer of tacit knowledge through the development of Information 
and Knowledge Systems (Negre \& Rosenthal-Sabroux, 2015) can support knowledge management in the context of smart cities and smart tourism destinations. The collective intelligence of people relies on the availability of the data provided by ICT for novel insights and value co-creation. Thus, leadership enabling the provision of open data to all people within the smart place to foster innovation co-creation through the collective intelligence of people is essential (Berry \& Glaeser, 2005). Tourism destination managers should take the lead in initiating smartness and in guiding all stakeholders through the changes required for the success of smartness. They must also understand the central role of tourists and residents (Buhalis \& Amaranggana, 2014) and empower a bottom-up approach to leadership once the smart tourism destination enters a more mature phase.

However, ecosystems cannot be created (Gretzel et al., 2015); they evolve (Moore, 1993) over time. Becoming a smart tourism destination requires patience, strategic management and continuous evaluation and change. Perceiving the smart tourism destination as an ecosystem is essential and a vision and a clear set of goals for innovation are key facilitators for smart tourism destinations as a collective whole

Figure 1: Smart Tourism Destination Framework 

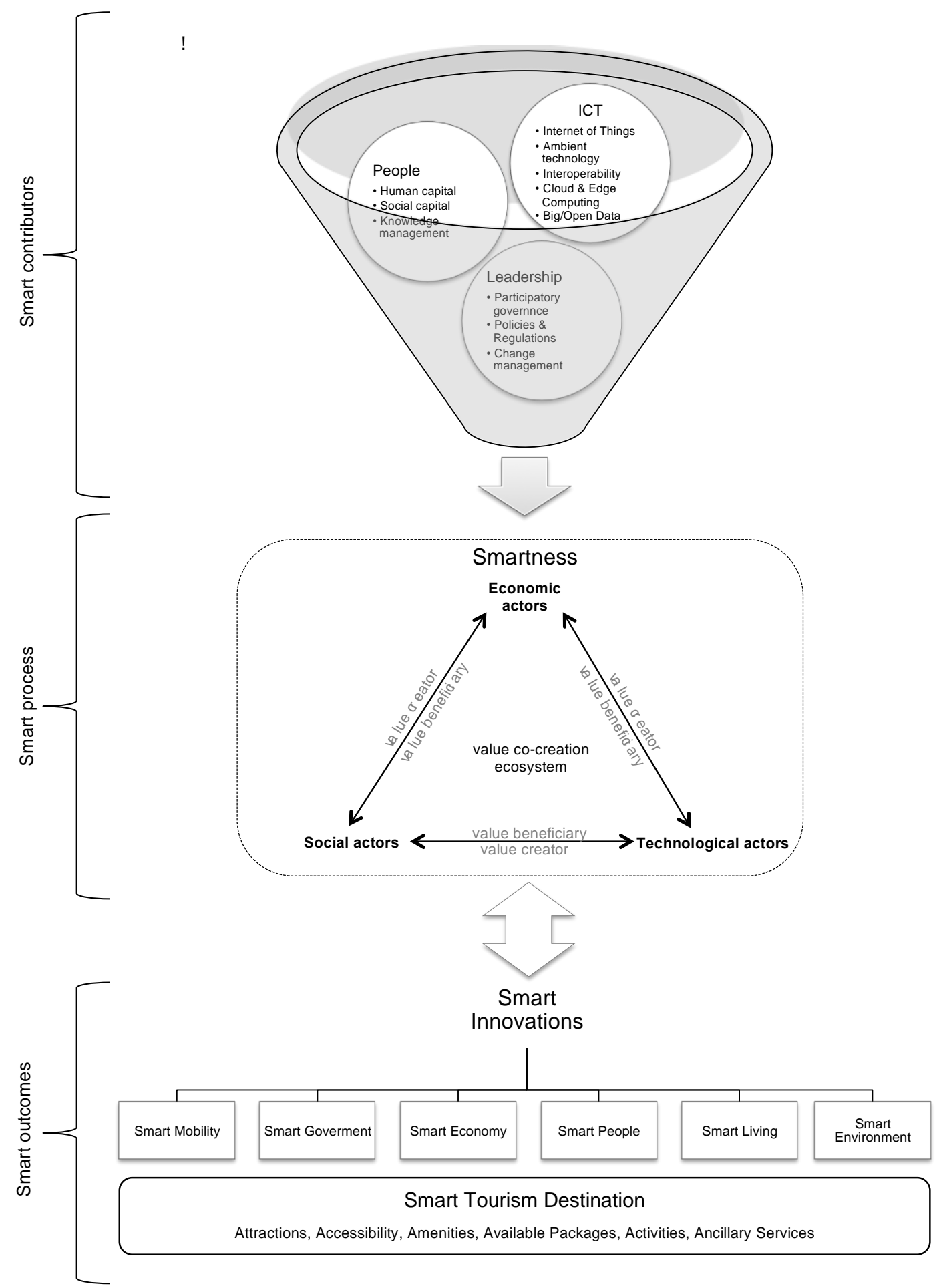

The final stage of the framework depicts the innovative outcomes of the S-D logic A2A ecosystem approach towards the smart tourism destination. The Smart City Wheel dimensions are a defined set of outcomes for any smart place (Cohen, 2011; Smart Cities Council, 2015). It ensures the development of innovations by enabling and fostering sustainable practises with both environmental and economical goals. It is within these six dimensions the co-creation of innovation and value are established. Smart tourism destinations are amalgamations of 
products and services often intertwined with the products and services provided by the city or geographical area it is situated in. Hence, the development of a smart tourism destination takes advantage of innovations established in the context of the Smart City Wheel dimensions focusing on accommodating the $6 \mathrm{~A}$ components of tourism destinations (Buhalis, 2000). However, tourism destination managers should also acknowledge their role in the development of innovation within these six dimensions in order for smartness to succeed in enhancing economic, social and environmental prosperity in smart tourism destinations.

\section{Conclusion}

Smart tourism destination management has become more complex since current developments in technology have empowered the collective integration of resources for value co-creation by all actors within the smart tourism destination ecosystem. This unique combination of interconnected and interoperable technological systems and knowledgeable networked people, enhances the potential for sustained competitive advantage in tourism destinations. However, in order to take full advantage of the current possibilities provided by smartness, destination managers have to integrate the entire range of smartness components and ensure interoperability and interconnection of both soft and hard smartness.

In other words, the results of this study suggest the sole integration of technology within a tourism destination will not suffice for becoming a smart tourism destination. Destination managers have to acknowledge the multi-facet construct of smartness to create value for all and enhance competitiveness of the destination. S-D logic has been here postulated as a meaningful theoretical approach towards the development of smart tourism destinations and can provide an underpinning for understanding the value co-creation process at the core of every smart initiative.

Whilst the focus of smart cities is on its residents, smart tourism destinations emphasise enhancing the tourist experience thereby simultaneously improving the quality of life for its residents. This twofold attention requires an inclusive ecosystem design, which can solely be achieved by dynamic leadership and by integrating all actors within the development of the smart tourism destination. Thus, the conceptualisation of smartness enables tourism destination managers to comprehend the different components and supports the implementation and utilisation of this concept.

Ultimately, smart tourism destination managers should understand the complexity between the different core components of smartness and how they are interlinked. This study conceptualised a holistic overview of the core components contributing to smartness. Still, more research is suggested in order to understand the interconnections between the different components and especially the interaction between people and hard smartness. Enabling the development of an inclusive ecosystem is essential to innovation and value co-creation and it is the role of hard smartness within this, acting as an operand and operant resource, which has yet to be identified and understood. 


\section{References}

Akaka, M., \& Vargo, S. (2014). Technology as an operant resource in service (eco)systems. Information Systems \& e-Business Management, 12(3), 367-384. doi:10.1007/s10257-013-0220-5

Albino, V., Berardi, U., \& Dangelico, R. M. (2015). Smart Cities: Definitions, Dimensions, Performance, and Initiatives. Journal of Urban Technology 22(1), 3-21. doi:10.1080/10630732.2014.942092

AMS. (2014). Partners. Retrieved from http://www.ams-amsterdam.com/partners/

Bakici, T., Almirall, E., \& Wareham, J. (2013). A Smart City Initiative: the Case of Barcelona. Journal of Knowledge Economy, 4, 135-148. doi:10.1007/s13132-012-0084-9

Baron, G. (2013). "Smartness" from the bottom up a few insights into the Amsterdam Smart City Programme.

Retrieved

from http://amsterdamsmartcity.com/data/file/Meteringlnternational BottomUp GB.pdf

Beeton, S. (2005). The Case Study in Tourism Research: a Multi-method Case Study Approach. In B. W. Ritchie, P. Bums, \& C. Palmer (Eds.), Tourism Research Methods: Integrating Theory with Practise (pp. 37-48). Wallingford: CABI Publishing.

Benbasat, I., Goldstein, D., \& Mead, M. (1987). The Case Research Strategy in Studies of Information Systems. MIS Quarterly, 11, 369-386.

Bergvall-Kåreborn, B., Ihlström Eriksson, C., Ståhlbröst, A., \& Svensson, J. (2009). A Milieu for Innovation : Defining Living Labs. Paper presented at the 2nd ISPIM Innovation Symposium, New York. https://pure.Itu.se/portal/files/3517934/19706123_Paper.pdf

Berry, C. R., \& Glaeser, E. L. (2005). The Divergence of Human Capital Levels Across Cities. Regional Science, 84(3), 407-444. doi:10.3386/w11617

Brinkman, J. (2011). Supporting sustainability through smart infrastructures: the case of Amsterdam. Network Industries Quarterly, 13(3), 22-25.

Bryman, A., \& Bell, E. (2011). Business research methods (3rd ed.). Oxford: Oxford University Press.

Buhalis, D. (2000). Marketing the competitive destination of the future. Tourism management, 21, 97-116. doi:10.1016/S0261-5177(99)00095-3

Buhalis, D. (2015). Working Definitions of Smartness and Smart Tourism Destination. Buhalis Blog. Retrieved from http://buhalis.blogspot.co.uk/2014/12/working-definitions-of-smartnessand.html

Buhalis, D., \& Amaranggana, A. (2014). Smart Tourism Destinations. In Z. Xiang \& L. Tussyadiah (Eds.), Information and Communication Technologies in Tourism 2014 (pp. 553-564). Dublin: Springer.

Cabiddu, F., Lui, T. W., \& Piccoli, G. (2013). Managing value co-creation in the tourism industry. Annals of Tourism Research, 42, 86-107. doi:10.1016/j.annals.2013.01.001

Campbell, N., O'Driscoll, A., \& Saren, M. (2012). Reconceptualising Resources: A Critique of ServiceDominant Logic. Paper presented at the 37th Macromarketing Conference, Berlin. http://search.ebscohost.com/login.aspx?direct=true\&db=edsoai\&AN=edsoai. 8058607 33\&site=edslive\&scope=sitehttp://arrow.dit.ie/buschmarcon/96http://arrow.dit.ie/cgi/viewcontent.cg i?article $=1097 \&$ context=buschmarcon

Caragliu, A., Del Bo, C., \& Nijkamp, P. (2011). Smart Cities in Europe. Journal of Urban Technology, 18(2), 65-82. doi:10.1080/10630732.2011.601117

Clarysse, B., Wright, M., Bruneel, J., \& Mahajan, A. (2014). Creating value in ecosystems: Crossing the chasm between knowledge and business ecosystems. Research Policy, 43(7), 1164-1176. doi:10.1016/j.respol.2014.04.014

Cocchia, A. (2014). Smart and Digital City: A Systematic Literature Review. In R. P. Dameri \& C. Rosenthal-Sabroux (Eds.), Smart City: How to Create Public and Economic Value with High Technology in Urban Space (pp. 13-43). Heidelberg: Springer International Publishing.

Cohen, B. (2011). Smart Cities Wheel. Retrieved from http://www.boydcohen.com/smartcities.html

Cohen, B. (2012). 6 Key Components for Smart Cities. Retrieved from http://www.ubmfuturecities.com/author.asp?section id=219\&doc id=524053

Cohen, B. (2014a). Leading Smart Cities Promote 5P Collaboration. Retrieved from http://www.ubmfuturecities.com/author.asp?doc id=526721

Cohen, B. (2014b). The 10 Smartest Cities In Europe. Retrieved from http://www.fastcoexist.com/3024721/the-10-smartest-cities-in-europe

Cohen, B. (2015, 15 June). Dr. @BoydCohen at "Brussels Smart City Summit": 3 generations of \#SmartCities. Retrieved from http://smartcities.i-ambiente.es/?q=blogs/dr-boydcohenbrussels-smart-city-summit-3-generations-smartcities

Cosgrave, E., Arbuthnot, K., \& Tryfonas, T. (2013). Living Labs, Innovation Districts and Information Marketplaces: A Systems Approach for Smart Cities. Procedia Computer Science, 16, 668-677. doi:10.1016/j.procs.2013.01.070

Dameri, R. P. (2013). Searching for Smart City definition: a comprehensive proposal. International Journal of Computers \& Technology, 11(5), 2544-2551. 
Dameri, R. P. (2014). Comparing Smart and Digital City: Initiatives and Strategies in Amsterdam and Genoa. Are they Digital and/or Smart? In R. P. Dameri \& C. Rosenthal-Sabroux (Eds.), Smart City (pp. 45-88). Cham: Springer International Publishing.

Dameri, R. P., \& Rosenthal-Sabroux, C. (2014). Smart City and Value Creation. In R. P. Dameri \& C. Rosenthal-Sabroux (Eds.), Smart City: How to create Public and Economic Value with High Technology in Urban Space (pp. 1-12). Heidelberg: Springer International Publishing.

De Filippi, P. (2015). Community Mesh Networks: Citizens' Participation in the Deployment of Smart Cities. In A. Vesco \& F. Ferrero (Eds.), Handbook of Research on Social, Economic, and Environmental Sustainability in the Development of Smart Cities (pp. 298-314). Hershey, PA: IGI Global.

Denyer, D., \& Neely, A. (2004). Introduction to special issue: Innovation and productivity performance in the UK. International Journal of Management Reviews, 5/6(3/4), 131-135. doi:10.1111/j.14608545.2004.00100.x

European Union. (2014). Mapping Smart Cities in the EU (PE 507.480). Retrieved from Brussels: http://www.europarl.europa.eu/RegData/etudes/etudes/join/2014/507480/IPOLITRE ET(2014)507480 EN.pdf

Forum Virium Helsinki. (2014). Smart City Innovation Unit. Retrieved from http://www.forumvirium.fi/en/smartcityinnovationunit

Fyall, A. (2011). Destination Management: Challenges and Opportunities. In Y. Wang \& A. Pizam (Eds.), Destination Marketing and Management: Theories and Implications (pp. 340-358): Cabi Publishing.

Geels, F. W. (2002). Technological transitions as evolutionary reconfiguration processes: a multi-level perspective and a case-study. Research Policy, 31, 1257-1274. doi:10.1016/S00487333(02)00062-8

Gillham, W. E. C. (2000). Case study research methods. London: Continuum.

Gretzel, U., Werthner, H., Koo, C., \& Lamsfus, C. (2015). Conceptual foundations for understanding smart tourism ecosystems. Computers in Human Behavior, 50, 558-563. doi:10.1016/j.chb.2015.03.043

GSMA. (2012). Finland: Forum Virium Helsinki. Retrieved from http://www.gsma.com/connectedliving/wpcontent/uploads/2012/12/cl forum virium 12 12.pdf

Hielkema, H., \& Hongisto, P. (2013). No Developing the Helsinki Smart City: The Role of Competitions for Open Data Applications. Journal of Knowledge Economy, 4(2), 190-204. doi:10.1007/s13132012-0087-6

Hollands, R. G. (2008). Will the real smart city please stand up? Intelligent, progressive or entrepreneurial? City, 12(3), 303-320. doi:10.1080/13604810802479126

IBM. (2014). Smarter Cities. Retrieved from http://www.ibm.com/smarterplanet/us/en/smarter cities/overview/?lnk=fktscit?lnk=fkt-smci-uken

Jamal, T., \& Jamrozy, U. (2006). Collaborative Networks and Partnerships for Integrated Destination Management. In D. Buhalis \& C. Costa (Eds.), Tourism management dynamics : trends, management, and tools (pp. 164-172). Amsterdam; Boston: Elsevier Butterworth-Heinemann.

Keeley, B. (2007). Human Capital: How what you know shapes your life. Paris: OECD.

La Rocca, R. A. (2014). The Role of Tourism in Planning the Smart City. Tema. Journal of Land Usre, Mobility and Environment, 7(3), 269-283. doi:http://dx.doi.org/10.6092/1970-9870-2814

Leiper, N. (2003). Tourism Management. Frenchs Forest: Pearson Education Australia.

Lin, N. (2001). Social capital : a theory of social structure and action. Cambridge: Cambridge University Press.

Lopez de Avila, A. (2015). Smart destinations: XXI century tourism Presented at the ENTER2015 Conference on Information and Communication Technologies in Tourism, Lugano, Switzerland, February 4-6, 2015.

Lusch, R. F., \& Nambisan, S. (2015). Service Innovation: A Service-dominant Logic Perspective. MIS Quarterly, 39(1), 155-176.

Maglio, P. P., \& Spohrer, J. (2013). A service science perspective on business model innovation. Industrial Marketing Management, 42, 665-670. doi:10.1016/j.indmarman.2013.05.007

Malek, A., \& Costa, C. (2015). Integrating Communities into Tourism Planning Through Social Innovation. Tourism Planning \& Development, 12(3), 281-299. doi:10.1080/21568316.2014.951125

McKercher, B. (1999). A chaos approach to tourism. Tourism Management, 20, 425-434. doi:10.1016/S0261-5177(99)00008-4

Meijer, A., \& Bolívar, M. P. R. (2015). Governing the smart city: a review of the literature on smart urban governance. International Review of Administrative Sciences. doi:10.1177/0020852314564308

Merriam-Webster. (Ed.) (2015) Merriam-Webster. @MerriamWebster.

Michaelides, R., Morton, S. C., Michaelides, Z., Lyons, A. C., \& Liu, W. (2013). Collaboration networks and collaboration tools: a match for SMEs? International Journal of Production Research, 51(7), 2034-2048. doi:10.1080/00207543.2012.701778 
Moore, J. F. (1993). Predators and prey: a new ecology of competition. Harvard Business Review, 71(3), 75-86.

Moss Kanter, R., \& Litow, S. S. (2009). Informed and Interconnected : A Manifesto for Smarter Cities. Harvard Business School Working Paper(No. 09-141, June 2009), 1-27.

Murphy, J., Kalbaska, N., Williams, A., Ryan, P., Cantoni, L., \& Horton-Tognazzini, L. C. (2014). Massive Open Online Courses: Strategies and Research Areas. Journal of Hospitality \& Tourism Education, 26(1), 39-43. doi:10.1080/10963758.2014.880618

Nam, T., \& Pardo, T. a. (2011). Conceptualizing smart city with dimensions of technology, people, and institutions. Paper presented at the Proceedings of the 12th Annual International Digital Government Research Conference on Digital Government Innovation in Challenging Times dg.o '11, New York.

Negre, E., \& Rosenthal-Sabroux, C. (2015). Smart Cities: A Salad Bowl of Citizens, ICT, and Environment. In A. Vesco \& F. Ferrero (Eds.), Handbook of Research on Social, Economic, and Environmental Sustainability in the Development of Smart Cities (pp. 61-78). Hershey, PA: IGI Global.

Orlikowski, W. J. (1992). The duality of technology: Rethinking the concept of technology in organizations. Organization Science, 3(3), 398-427.

Pirnar, I., Bulut, C., \& Eris, E. D. (2012). Improving The Performance and Competitiveness of Tourism Establishments by Means of Innovation: Trends And Applications. Paper presented at the Enlightening Tourism: 1st International Conference Competition and Innovation in Tourism: New Challenges in an Uncertain Environment, Napels.

Piro, G., Cianci, I., Grieco, L. A., Boggia, G., \& Camarda, P. (2014). Information centric services in Smart Cities. The Journal of Systems \& Software, 88, 169-188. doi:10.1016/j.jss.2013.10.029

Porter, M. E. (1998). The competitive advantage of nations. Basingstoke: Macmillan Business.

Porter, M. E., \& Heppelmann, J. E. (2014). How Smart, Connected Products Are Transforming Competition. Harvard Business Review, 92(11), 64-88.

Porter, M. E., \& Kramer, M. R. (2011). Creating shared value. Harvard Business Review, 89(1/2), 62-77.

PWC. (2014). Barcelona as a Smart City Lessons learned from the evolution of the concept and the influence in the city attractiveness. Retrieved from http://www.economistasmadeira.org/files/Apresentacoes $\quad$ CAT/1Barcelona_like_a_Smart_City_v6_03042014.pdf

Ritchie, J. R. B., \& Crouch, G. I. (2003). The competitive destination : a sustainable tourism perspective. Wallingford: CABI Pub.

Rushton, A. M., \& Carson, D. J. (1985). The Marketing of Services: Managing the Intangibles. European Journal of Marketing, 19(3), 19.

Scott, N., Baggio, R., \& Cooper, C. (2008). Network analysis and tourism : from theory to practice. Clevedon; Buffalo, NY: Channel View Publications.

Shaw, G., Bailey, A., \& Williams, A. (2011). Progress in Tourism Management: Aspects of servicedominant logic and its implications for tourism management: Examples from the hotel industry. Tourism Management, 32, 207-214. doi:10.1016/j.tourman.2010.05.020

Smart Cities Council. (2015). Smart Cities Council | Definitions and overviews. Retrieved from http://smartcitiescouncil.com/smart-cities-information-center/definitions-andoverviews

Spencer, A. J., Buhalis, D., \& Moital, M. (2012). A hierarchical model of technology adoption for small owner-managed travel firms: An organizational decision-making and leadership perspective. Tourism Management, 33, 1195-1208. doi:10.1016/j.tourman.2011.11.011

Tuohino, A., \& Konu, H. (2014). Local stakeholders' views about destination management: who are leading tourism development? Tourism Review, 69(3), 202-215. doi:doi:10.1108/TR-06-20130033

van Veen, A. (2014). Measuring the Smart City. Retrieved from http://iet.jrc.ec.europa.eu/energyefficiency/sites/energyefficiency/files/files/documents levents/slidesvanveenamsterdam.pdf

Vargo, S. L., \& Lusch, R. F. (2004). Evolving to a New Dominant Logic for Marketing. Journal of Marketing, $68(1), 1-17$

Vargo, S. L., \& Lusch, R. F. (2008). Service-dominant logic: continuing the evolution. Journal of the Academy of Marketing Science, 36(1), 1-10.

Vargo, S. L., \& Lusch, R. F. (2011a). It's all B2B... and beyond: Toward a systems perspective of the $\begin{array}{llll}\text { market. Industrial Marketing } \quad \text { Management, } & \text { 40(2), }\end{array}$ doi:10.1016/j.indmarman.2010.06.026

Vargo, S. L., \& Lusch, R. F. (2011b). Reducing the fear of crime in a community: A logic of systems \& system of logics perspective Presented at the Grand Challenge in Service Week: Understanding Complex Service Systems Through Different Lens. Cambridge.

Vargo, S. L., Maglio, P. P., \& Akaka, M. A. (2008). On value and value co-creation: A service systems and service logic perspective. European Management Journal, 26, 145-152. doi:10.1016/j.emj.2008.04.003 
Vargo, S. L., Wieland, H., \& Akaka, M. A. (2015). Innovation through institutionalization: A service ecosystems perspective. Industrial Marketing Management, 44, 63-72. doi:10.1016/j.indmarman.2014.10.008

von Bertlanffy, L. (1972). The history and status of general systems theory. Academy of Management Journal, 15(4), 407-426.

Wakelin, M. (1992). Globalization of regional development. In D. V. Gibson, G. Kozmetsky, \& R. W. Smilor (Eds.), The Technopolis phenomenon: smart cities, fast systems, global networks (pp. 43-52). Savage: Rowman \& Littlefield Publishers.

Wang, D., Li, X., \& Li, Y. (2013). China's "smart tourism destination" initiative: A taste of the servicedominant logic. Journal of Destination Marketing \& Management, 2(2), 59-61. doi:10.1016/j.jdmm.2013.05.004

Wieland, H., Polese, F., Vargo, S. L., \& Lusch, R. F. (2012). Toward a Service (Eco)Systems Perspective on Value Creation. International Journal of Service Science, Management, Engineering, and Technology, 3(3), 12-25. doi:10.4018/jssmet.2012070102

Yigitcanlar, T., Velibeyoglu, K., \& Martinez-Fernandez, C. (2008). Rising knowledge cities: The role of urban knowledge precincts. Journal of Knowledge Management, 12(5), 8-20. doi:10.1108/13673270810902902

Yin, R. K. (2009). Case study research : design and methods (4th ed.). Los Angeles: Sage. 